\title{
Analysis Of The Effect Of Net Profit, Operational Cash Flow, Free Cash Flow, Previous Year Cash Dividends On Cash Dividends In The Indonesia Stock
}

\author{
Fatia Fatimah ${ }^{1 *}$, Sifriyani ${ }^{2}$, Deni sunaryo ${ }^{3}$, Etty Puji lestari ${ }^{4}$ \\ ${ }^{1,4}$ Universitas Terbuka, ${ }^{2}$ Universitas Mulawarman, ${ }^{3}$ Universitas Serang Raya \\ ${ }^{*}$ Corresponding author: \\ Email: fatia@campus.ut.ac.id
}

\begin{abstract}
.
This study aims to determine the analysis of the effect of net income, operating cash flow, free cash flow, cash dividends in the previous year, on cash dividends. This study uses a food and beverage sub-sector research design. The research population amounted to 18 companies for 5 years from 2014-2018 and were picked up by 7 companies in a row to publish their financial statements. The method used in this data analysis using multiple linear regression analysis. Based on the results of the study, it can be concluded that: net income has no effect on cash dividends, operating cash flow has no effect on cash dividends, free cash flow has no effect on cash dividends, previous year's cash dividends have an effect on cash dividends.recommendations The company should pay attention to the cash dividend payments in previous years as an independent variable that affects the current year's cash dividend. Because the company will be attractive to shareholders whose preferences are related to dividend payout and stability. Investors want a stable dividend as a source of income embedded in shares that are paid the same amount of dividends every period. For further researchers, it is better to add the number of samples in the observation period of 6 years or 7 years, adding other variables such as Analyzing the relationship between Net profit, Operating Cash Flow with cash dividends, or Effect of accounting profit, cash profit, Free Cash Flow, Operating Cash Flow, leverage and current ratio to cash dividend. and can expand the research sample, not only to manufacturing companies but to more than one type of company
\end{abstract}

Keywords: Net income, operating cash flow, free cash flow, cash dividends

\section{INTRODUCTION}

One alternative that can be chosen by investors to invest in the capital market is by buying shares. Nining and Dwi (2016) stated that there are two advantages that can be obtained from stock investment, namely the distribution of dividends and also capital gains (increase in stock prices). Dividend is the distribution of profits to shareholders in proportion to the number of shares owned, either in the form of cash dividends or stock dividends (Ardiyos, 2013: 161). While the capital gain is the difference between the selling price and the purchase price. Generally, dividends have a lower risk than capital gains. In determining the amount of dividends to be distributed, managers must make a policy called dividend policy. Triatmojo (2016) explains that dividend policy is a decision whether the profits earned by the company will be distributed as dividends or instead retained in the form of retained earnings in order to finance the company's investment in the future. Djoko and Bambang (2016) stated that dividend policy is a difficult decision for companies. Dividend distribution 
on the one hand can affect the interest of investors to invest their capital and will also affect the existence of the company in the capital market where the capital market is one of the important sources for companies to fund their business activities while on the other hand dividend distribution is also expected not to threaten the survival of the company. Therefore, company managers must be able to make optimal dividend policies. Brigham and Houston (2011: 221) state that the optimal dividend policy is a policy that balances the amount of current dividends with future company growth so as to maximize share prices. The distribution of dividends by several companies in Indonesia is still inconsistent.

This can be seen from several phenomena that occur in manufacturing companies, for example the case of PT. Sekar Laut, Tbk which in 2009 did not distribute dividends to shareholders even though the net profit of its business increased three times from the previous year. John Gozal director of PT. Sekar Laut, Tbk revealed that the reason the company did not distribute dividends even though its profits rose significantly was because the company wanted to develop its business. The profit was invested to buy a new machine (kabarbisnis.com). It is different with larger companies such as PT. Unilever Indonesia, Tbk which in 2015 increased the amount of dividend distribution to investors even though the company's net profit decreased. The company's net profit in 2014 was Rp. 5.93 trillion while in 2015 it fell to Rp. 5.85 trillion. This happens because the company's operating expenses PT. Unilever Indonesia, Tbk increased (viva.co.id). Based on this phenomenon, the researchers chose the manufacturing industry as the sample in this study. Apart from the inconsistency of dividend distribution as described above, another reason is because the manufacturing industry is the industry with the most shares listed on the Indonesia Stock Exchange (IDX) and also consists of various types of industrial sub-sectors. Djoko and Bambang (2016) state that the existence of these various industrial subsectors makes the manufacturing sector almost dominate the capital market, so it is easier to see the effect of the capital market as a whole. There are several factors that influence the company in determining the amount of dividends to be distributed. Based on the phenomena that occur above, the researchers set four factors that influence dividend policy.

Hery (2012: 287) Companies that have a fairly good level of net profit accumulation from the next period, usually have the potential to be able to share part of the net profit to company owners (shareholders). dividend. Abdul Dalimunte (2013) also said that in determining the cash dividend to be given to shareholders, of course the company will pay attention to the net profit obtained by the company, because the dividends distributed to shareholders are part of the profit, if a company can earn greater profits, then theoretically the company will be able to set a larger cash dividend. The amount of dividend payment is different every year, sometimes when the company's profit decreases, but the dividends given by the company are actually greater than the previous year (Abdul Dalimunthe, 2013). However, the net profit 
reflected in the company's income statement uses accounting income so that it does not describe the availability of cash to pay the dividend (Miller \& Modigliani, 1961 in Jurica Lucyanda and Lilyana, 2012).

Hery (2017, p. 215): "Stating operating activities include transactions classified as determining the amount of net profit/loss. Cash receipts from the sale of goods or rendering of services are the main source of cash inflows. The amount of cash flow from operating activities is an indicator that determines whether the company's operating activities can generate sufficient cash flow to repay loans, maintain the company's operating capability, pay dividends, and make new investments without relying on sources of income. Therefore, if the company has a low operating cash flow, it can affect the payment of cash dividends. Cash flow from operating activities depends on the company's investment. In other words, investments made by companies that produce projects with positive net present value will increase cash flow from operating activities. Dividend distribution also depends on the company's liquidity position, which is reflected in the operating company's cash flow. Operating Cash Flow describes the liquidity of cash flows out and into the company. From the company's cash flow report, it can be seen how much the company's ability to fulfill its obligations including cash dividends. The company's operating cash flow is an indicator to measure how the company manages existing cash, companies that are able to maintain good cash are able to meet internal needs and are sufficient to pay dividends.

According to the theory of Tatang Ary Gumanti (2013 p. 46) "Stating that the total cash inflows (from operating profit and external funding) must be equal to the cash outflows (for investments and dividends)". This means that if Operating Cash Flow increases, dividend payments will also increase, and vice versa, dividend payments decrease because Operating Cash Flow has decreased.Free Cash Flow (free cash flow). According to Murhadi (2013: 48) Free Cash Flow is cash available within the company and can be used for various activities. The cash is obtained from the company's operating activities after being used for reinvestment activities. From this definition, it can be said that Free Cash Flow is the remaining excess cash in the company that should be distributed in the form of dividends to shareholders. Companies that have high Free Cash Flow make investors demand to distribute it in the form of dividends. As a result, the dividends to be distributed will also be large. Therefore, Free Cash Flow (free cash flow) has a positive influence on dividend policy. The higher the Free Cash Flow, the higher the dividend to be distributed and vice versa.

Cash dividend payments in the previous period should also be considered in explaining the variation of cash dividends paid in the current period. The dividend announcement is one of the information that the market will respond to. When dividend payments for the previous period are made, especially cash dividends, the market will respond, so managers will distribute cash dividends to show that the 
company has good prospects for the current period. This means that the greater the Previous Cash Dividend payment, the greater the probability that the Cash dividend will be distributed during this period. The results of research conducted by Arfan (2011) stated that there was a significant effect between Previous Cash Dividend payments and Cash dividends.

\section{LITERATURE REVIEW AND HYPOTHESES DEVELOPMENT Dividend}

Dividend is a distribution to shareholders of a company proportionally according to the number of shares held by each owner (Stice et al. 2009:138). According to Harahap (2008:295) dividend is part of the profit received by the owner of the company. The distribution of this dividend is based on profit, both retained earnings and profit for the year. Theoretically without profit there is no dividend. The payment of dividends is at the discretion of the company's board of directors. According to Kieso and Weygandt (2010:185), which is translated by Desi Adhariani and Vera Diyanti, dividends (dividends) are distributed by the company to its shareholders on a pro rata basis (professional). The decision to give dividends has an effect on the assessment and growth of the company. Companies that are "growing" will pay cash dividends in small amounts or do not pay dividends because their policy is to expand rapidly as far as internal and external financial conditions allow. In general, investors in receiving dividends prefer the company to pay dividends in cash. The purpose of dividend distribution according to Handayani (2010) in Hariyanto (2013:14) is as follows: To maximize prosperity for shareholders This is because some investors invest their funds in the capital market to obtain dividends and the high dividend paid will affect stock prices.

Investors believe that the high dividends paid means that the company's future prospects are good. To show the company's liquidity. By paying dividends, it is expected that the company's performance in the eyes of investors is good. We often find that some companies pay dividends in a fixed amount for all periods. This is done because the company wants to be recognized by investors that the company concerned is able to face economic turmoil and is able to provide returns to investors. Some investors view that the risk of dividends is lower than the risk of capital gains. To meet the needs of shareholders, they will get fixed assets which are used for consumption purposes. Dividends can be used as a consumable tool between managers and shareholders. Overall information about the condition of the company is often unknown to investors so that through dividends the company's growth and company prospects and company prospects can be known. There are several types of dividends that companies pay to shareholders. Meanwhile, according to Ang (1997) In Hariyanto (2013:!2), in terms of the shape there are 2 (two) types of dividends, namely: cash dividends (cash dividends), stock dividends (stock dividends). 


\section{Profit}

According to Subramanyam and Wild (2010:4) translated by Dewi Yanti, profit is the difference between income and profit after deducting expenses and losses. Profit is one of the measurements of operating activities and is calculated on the basis of accrual accounting. The income statement presents the net profit for a period along with the components of profit, namely revenues, expenses, gains, and losses. Profit summarizes the financial impact of business operating activities. The main purpose of the income statement is to explain how profit is calculated with the important components presented in separate items.

According to Riahi and Belkaoui (2007:226) profit is a fundamental and important aspect of financial statements and has many uses in various contexts. Profit is generally viewed as a basis for taxation, a determinant of dividend payout policy, a guide to investment and decision making, and an element in forecasting. According to Soemarso (2009:227), the last number in the income statement is net profit (net profit). This amount represents the net increase in capital. On the other hand, if the company suffers a loss, the last number in the income statement is the net loss. The Committee on Terminology defines profit as the amount that comes from reducing the cost of production, other costs, and losses from income or operating income (Harahap, 2007).

\section{Cash flow statement}

According to Stice et al (2009:284) translated by Ali Akbar, the cash flow statement describes changes in cash or cash equivalents within a certain period. Cash equivalents are highly liquid short-term investments that can be readily exchanged for cash. To be considered a cash equivalent, an item must be immediately convertible into cash and very close to its maturity so that there is little risk of changes in value due to changes in or due to interest rates. The cash flow statement presents more detailed information about cash accounts, both in the form of cash inflows and cash outflows of the company for 1 period. Information about cash flows is useful for users of financial statements to evaluate the company's ability to generate cash and assess the company's need for cash (PSAK No. 2, Introduction, 2009).

Furthermore, the standard (PSAK No. 2, par. 3, 2009) states that the statement of cash flows, together with other financial statements, is expected to produce information that allows users to evaluate changes in net assets, financial structure, and the company's ability to run its business. in the face of business changes (Warsono and Natalia, 2011).The purpose of the cash flow statement to present a cash flow statement is to provide relevant information about the receipts and disbursements of cash or cash equivalents from a company in a certain period (Harahap, 2008:255). This report will help investors, creditors, and other users to: assess the company's ability to generate cash in the future; assess the company's ability to meet its obligations to pay dividends and the need for funds for external activities; assess the reasons for the difference between Net profit and associated cash receipts and disbursements; assessing the effect 
of both cash and non-cash investments and other financial transactions on the company's financial position during a certain period.

\section{Grouping in the Statement of Cash Flows}

According to experts, in the cash flow statement, cash receipts and disbursements are grouped into three main categories, namely Operating Cash Flow, investment cash flow, and financing/funding cash flow. The explanation of each of these categories is as follows.

\section{Operating Cash Flow}

Activities included in this group are the main income generating activities of the company and other activities that are not investing and financing activities; all transactions and other events that cannot be considered as investment and financing activities. These activities usually include production activities, delivery of goods, and the provision of services. Cash flows from these operations are generally the effects of cash from transactions and other events that participate in determining profit. The amount of cash flow from operating activities is an indicator that determines whether the company's operations can generate sufficient cash flow to repay loans, maintain the company's operating capability, pay dividends and make new investments without relying on external funding sources.

According to Kieso and Weygandt (2010:323) translated by Desi Adhariani and Vera Diyanti, the category of operating activities is the most important. This source of cash is generally considered the best measure of a company's ability to obtain funds to continue its business. The net amount provided or used by operating activities is an important feature of a cash flow statement. Just as Net profit is used to summarize everything in the cash flow statement, cash flow from operating activities is the "bottom line" or the final amount of the cash flow statement. Although cash flows from interest or dividends can logically be classified as investing or financing activities, the FASB decided to classify them as operating activities.

\section{Investment Cash Flow}

Activities included in investment cash flows are the acquisition and disposal of long-term assets, both tangible and intangible and other investments that do not include cash equivalents, including receiving and collecting loans, debts, securities or capital, fixed assets and other productive assets. used in the production process.

\section{Financing/Funding Cash Flow}

Activities that include financing are activities that result in changes in the amount and composition of the company's capital and long-term loans, in the form of activities to obtain sources of funds from owners by providing income prospects from these sources of funds, borrowing and repaying debts or making long-term loans to repay certain debts. .

\section{Free Cash Flow}

Free Cash Flow is the amount of cash flow that remains after a company makes investments in assets needed to support operations. In other words, Free Cash 
Flow is the amount of cash flow available for distribution to investors, so the value of the company will be directly affected by its ability to generate cash flow. According to Kieso and Weygandt (2010: 350) translated by Desi Adhariani and Vera Diyanti, Free Cash Flow describes the amount of cash remaining from operations after adjustments for the purchase of fixed assets (capital expenditures) and dividend payments. Free Cash Flow is cash generated from operating activities adjusted for the purchase of fixed assets and cash dividend payments.

\section{Previous Year's Cash Dividend}

The previous year's cash dividend is the cash dividend paid by the company this year for the dividends announced in the previous year, and can be seen in this year's statement of changes in company equity. The previous year's cash dividend used in this study is the cash dividend per share (dividend per share) which is calculated by the following formula (Sundjaja and Barlian, 2003)

\section{Hypothesis Development}

Based on the research model, the following hypotheses can be put forward in this study:

\section{Effect of Profit on Cash Dividend}

Dividends are part of the profits received by the owners of the company and this distribution is based on the profits generated by the company. According to Sundjaja and Barlian (2003), cash dividends are obtained from the ratio of total dividends to the number of shares, where total dividends are obtained from the difference between net income and changes in retained earnings. Thus, profit is the main indicator in paying dividends. According to Riahi and Belkaoui (2007), translated by Ali Akbar Yulianto and Krista, profit is recognized as an indicator of the maximum amount that can be distributed as dividends and retained for expansion or reinvested into the company. According to Stice et al (2009) translated by Ali Akbar, the main focus of financial statements is profit, and profit information is the best indicator of the company's ability to generate cash in the future than information about current period cash flows. The research on the relationship between earnings and dividends was conducted by Hermi (2004), who found that net income had a significant relationship with cash dividends. Murtanto and Yuridya (2004) examine the relationship between accounting earnings and cash earnings with cash dividends, the result is that earnings have a positive and strong relationship with cash dividends.

The results of research by Ramli and Arfan (2011) show that net income has a positive and significant effect on cash dividends. Generally, the distribution of profits is based on the number of shares owned by the company or known as the distribution of earnings per share (Earnings per share / EPS). Earning per share is the level of net profit that can be achieved by the company when carrying out its operations. The distribution of profits or dividends is distributed if the company makes a profit. Profits that deserve to be distributed to shareholders are profits after the company has fulfilled all interest and tax obligations (Ramli and Arfan, 2011). The amount of earnings per 
share (earnings per share / EPS) is the ratio between net income after interest and taxes with the number of shares outstanding, which is usually the focus of investors to assess the company's ability to generate net profits in each share. However, this value does not always affect the amount of cash dividends that will be received by shareholders.

This is because, (1) EPS can lead to wrong decision making, if it is not related to the assessment and analysis of the income statement; (2) reported EPS cannot be compared over time between companies; and (3) EPS only focuses investors' attention on a single number without paying attention to the company as a whole which can provide information about the source and characteristics of earnings and provide the basis for projected earnings and dividends. Research results (Widiharti, 2011:65). Shows that net income has no effect on cash dividends. The results of the study (Siska Riani Siregar 2019) are based on research results if the company has a good level of net income, the company has the potential to distribute part of its profits to shareholders and vice versa when the net profit earned by the company decreases then the company's potential to distribute dividends also decreased. The results show that net income has an effect on cash dividends from the description and existing research, the first hypothesis is as follows.

\section{H1 : Net Profit has an effect on Cash Dividend}

\section{Effect of Operating Cash Flow on Cash Dividend}

Operating activities are the main income generating activities of the company and other activities that are not investing and financing activities. Cash flows from these operations are generally the effects of cash and transactions and other events that participate in determining earnings (Harahap, 2008). According to Darsono and Ashari (2005:22), the amount of cash flow originating from operating activities is an indicator that determines whether the company's operations can generate sufficient cash flow to repay loans, maintain the company's operating capability, pay dividends and make new investments without relying on external sources of funding. Hermi (2004) examines the relationship between operating cash flows and cash dividends, the result is that operating cash flows have a significant relationship with cash dividends. PSAK 2 (revised 2009) explains that interest paid and interest or dividends received can be classified as cash flows from operating activities, because they are seen as determining the entity's profit or loss in a certain period (Martani, 2012: 148). According to Kieso and Weygandt (2010:324) translated by Desi Adhariani and Vera Diyanti, although cash flows from interest or dividends can logically be classified as investing or financing activities, the FASB decided to classify both as operating activities. The basic principle is that operating activities contain the effects of cash flows from income and expenses in the income statement.

The results of this study are in accordance with research conducted by Ramli and Arfan (2011) which states that operating cash flow does not have a significant positive effect on cash dividends. The same result is also shown by research conducted by Danussiswanta (2002) In the cash flow statement, cash generated by operating 
activities is intended to indicate the company's ability to generate cash. However, analysts have realized that the cash generated by an operating activity fails to take into account that a company should invest in new fixed assets just to maintain its current operating level. Companies should also at least maintain dividends at the current level to satisfy investors (Kieso and Weygandt, 2010:350). Research results (Ramli and Arfan 2011) Based on this research, operating cash flow describes good company performance and generates high operating cash flow so that it can distribute relatively high dividends. Then the greater the company's operating cash flow, the greater the ability to distribute dividends. The results show that operating cash flow has an effect on cash dividends from the description and existing research, the second hypothesis is as follows.

\section{H2 : Operating Cash Flow has an effect on Cash Dividend}

\section{Effect of Free Cash Flow on Cash Dividend}

The greater the company's cash position, the greater the company's ability to pay dividends. Cash availability is considered more important than net income to pay cash dividends. The existence of net income which is the basis for dividend distribution is often not matched by the availability of cash to be used for cash dividend payments. The cash position factor that is actually available to shareholders will be reflected in the free cash flow owned by the company to be distributed to investors. According to Brigham and Houston (2009:65) which is translated by Ali Akbar Yulianto, free cash flow is cash flow that is actually available for distribution to all investors (shareholders and debt owners) after the company places all of its investment in fixed assets, products and services. new products, and the working capital needed to maintain ongoing operations. The value of a company's operations will depend on all of its expected future free cash flows, which are defined as after-tax operating profit minus the amount of investment in working capital and fixed assets required to maintain the business. According to Jensen (1986) in Hatta (2002), one of the purposes of using free cash flow is to distribute dividends to shareholders. Research on the effect of free cash flow on cash dividends has been conducted by Ramli and Arfan (2011) who found that free cash flow has a positive and significant effect on cash dividends. Rosdini (No Year) examined the effect of free cash flow on dividend policy, and the results showed that free cash flow had a positive effect on dividend policy. The results of this study are in accordance with research conducted by Hatta (2002) which states that free cash flow has no effect on cash dividends.

The greater the company's cash position, the greater the company's ability to pay dividends. The cash position factor that is actually available to shareholders will be reflected in the free cash flow owned by the company to be distributed to investors. If the condition of free cash flow applies continuously, then the present value of free cash flow will be even greater, and the value of the company will be greater in the eyes of investors. However, this amount is not always used to be distributed to shareholders as cash dividends.The results of the study (Ika Sri Viviani in 2018) These results indicate 
that the greater the free cash flow owned by the company, the company tends to distribute high dividends to shareholders. When viewed from the ratio used in this study, if the free cash flow value is high, this indicates that the operating cash flow owned by the company is high because the company experiences a lot of inflows (cash inflows) so that it will affect the amount of increase in dividends to be distributed. Conversely, if the value of free cash flow is low, it indicates that the operating cash flow owned by the company is also low because the company experiences a lot of outflows (cash out) so that it will reduce the amount of dividends to be distributed. The results show that free cash flow has an effect on cash dividends from the description and existing research, the third hypothesis is as follows.

\section{H3 : Free Cash Flow has an effect on Cash Dividend}

\section{Effect of Previous Year's Cash Dividend Payment on Current Year's Cash} Dividend.

Dividends are part of the profits received by shareholders. According to Kieso and Weygandt (2010: 185) which is translated by Desi Adhariani and Vera Diyanti, cash dividend is a pro rata distribution of cash to shareholders. According to Danussiswanta (2002), the previous year's dividend distribution report, if any, can also explain the current year's dividend distribution. In his research, he found that the previous year's dividend distribution had an effect on the current year's dividend distribution. According to Lintner in Danussiswanta (2002), the independent variable of previous dividend distribution can affect the current year's dividend distribution. In accordance with the dividend irrelevance theory proposed by Merton H. Miller and Franco Modigliani (2002), the company will be attractive to shareholders whose preferences are related to dividend payments and stability are related to the payment pattern and the stability of the company's pattern itself. Investors want stable dividends as a source of income embedded in shares that are paid the same amount of dividends every period (Sundjaja and Barlian, 2003). According to Hermi in Ramli and Arfan (2011), dividend announcements and earnings announcements in the previous period are the two types of announcements most often used by managers to inform the company's achievements and prospects.

Ross (1977) in Danussiswanta (2002), in his research proves that an increase in dividend payments can lead to clear and unbeatable conditions on the market that the company's prospects have progressed. The results of research by Ramli and Arfan (2011) show that the previous year's cash dividend payment has a positive and significant effect on the current year's cash dividend. These results support Lintner's theory (Danussiswanta, 2002), which states that the independent variable of previous dividend distribution affects the current year's dividend distribution. In accordance with the dividend irrelevance theory proposed by Merton H. Miller and Franco Modigliani, the company will be attractive to shareholders whose preferences are related to dividend payments and stability are related to the payment pattern and the stability of the company's pattern itself. Investors want a stable dividend as a source of 
income embedded in shares that are paid the same amount of dividends every period. The results show that the previous year's cash dividends have an effect on cash dividends from the description and existing research, the four hypotheses are as follows.

H4: Previous Year's Cash Dividend Payment has an effect on Current Year's Cash Dividend

\section{METHODS}

The research method used in this research is associative research method with a causal relationship. According to Sugiyono (2012: 59) a causal relationship is a causal relationship. So, here there are independent variables (influence) and dependent variables (influenced).The type of research used is quantitative research. Quantitative research is a research method that is based on the philosophy of positivism, used to examine a particular population or sample. Data collection uses research instruments, analyzes and is quantitative or statistical in nature with the aim of testing the established hypothesis (Sugiyono, 2016: 08). In this study the data used is secondary data. Secondary data is data that refers to information collected from existing sources. Secondary data sources are the financial statements of food and beverage companies listed on the Indonesia Stock Exchange in 2014-2018.

The population in this study are food and beverage sub-sector manufacturing companies listed on the Indonesia Stock Exchange (IDX) for the 2014-2018 period. The population of food and beverage companies listed on the Indonesian stock exchange is 18 companies. In the study, the researcher will use a purposive sampling technique, namely the sample is taken based on certain criteria in accordance with the research objectives which are considered representative of the research sample studied as follows: Manufacturing companies listed on the Indonesia Stock Exchange during the research period, namely 2014-2018.

Companies that have a positive net profit. Companies that have a positive Free Cash Flow report. Companies that pay dividends for the current year. Companies that use the rupiah currency in the preparation of financial statements. Based on the selection criteria for the sample that will be examined by food and beverage companies listed on the BEI, 7 companies are obtained. Because this research was conducted within 5 years (2014-2018), the number of observations was 35 companies. In this analysis using tests including: Descriptive Statistics, Classical Assumption Test (Normality Test, Multicollinearity Test, Autocorrelation Test, Heteroscedasticity, Multiple Linear Regression Analysis), Hypothesis Testing (partial and Simultaneous), Coefficient of Determination (R2) 


\section{RESULTS AND DISCUSSIONS}

\subsection{Descriptive statistics}

Descriptive analysis in this study is intended to provide an overview of the data used for each variable. The observed values from this analysis are the minimum, maximum, average (mean), and standard deviation values.

\section{Table 4.2.}

Descriptive Statistics Test Results

\begin{tabular}{lr|r|r|r|r} 
& N & Minimum & Maximum & Mean & Std. Deviation \\
\hline $\begin{array}{l}\text { Previous year's cash } \\
\text { dividend }\end{array}$ & 35 &, 0023 & 1,2571 &, 092029 &, 2118162 \\
\hline Cash dividend & 35 &, 0004 &, 2618 &, 058138 &, 0622231 \\
\hline Free Cash Flow & 35 & 13,2636 & 28,4798 & 21,283786 & 5,2473455 \\
\hline NET PROFIT & 35 &, 0002 & 245,7520 & 32,185832 & 53,2954767 \\
\hline Operating Cash Flow & 35 & - & 274318354 & 264399914 & 601335956737,6 \\
& & 2921328880 & 1210 & 488,00 & 97 \\
\hline Valid N (listwise) & 35 & & & & \\
\hline
\end{tabular}

Source: processed data, 2019.

\section{Normality test}

According to Ghozali (2018:161), "The normality test aims to test whether in the regression model, the confounding variable or residual has a normal distribution". A good regression model is to have a normal data distribution or close to normal (Ghozali, 2018:163). The normality test of the data can also use the KolmogorovSmirnov (K-S) non-parametric statistical test to determine the significance of normally distributed data. Furthermore, an overview is obtained as shown in the table below:

Table 4.3. Normality test

One-Sample Kolmogorov-Smirnov Test

Unstandardized Residual

\begin{tabular}{|c|c|c|}
\hline \multicolumn{2}{|l|}{$\mathrm{N}$} & 30 \\
\hline \multirow[t]{2}{*}{ Normal Parameters ${ }^{\mathrm{a}, \mathrm{b}}$} & Mean &, 0000000 \\
\hline & $\begin{array}{l}\text { Std. } \\
\text { Deviation }\end{array}$ & ,06438267 \\
\hline \multirow{3}{*}{$\begin{array}{ll}\text { Most } & \text { Extreme } \\
\text { Differences } & \end{array}$} & Absolute & , 137 \\
\hline & Positive & ,137 \\
\hline & Negative &,- 077 \\
\hline \multicolumn{2}{|l|}{ Test Statistic } & ,137 \\
\hline \multicolumn{2}{|l|}{ Asymp. Sig. (2-tailed) } &, $160^{c}$ \\
\hline
\end{tabular}

\section{Discussion}

\section{Effect of Profit on Cash dividend}

The test results of this study indicate that the variable The effect of earnings on cash dividends has no effect, which is indicated by the value of tcount $<-$ ttable ($0.926<-2.040)$ and the level of influence is $0.362>0.05$. These results do not support 
the previously proposed $\mathrm{H} 1$ or it can be said that the hypothesis is rejected. Which means that the distribution of the company's net profit affects the amount of dividends that will be distributed so that the net profit does not affect the cash dividend. The amount of Net profit per share (earnings per share/ EPS) is the ratio between Net profit after interest and taxes with the number of shares outstanding, which is usually the focus of investors to assess the company's ability to generate net profits in each share. However, this value does not always affect the amount of cash dividends that will be received by shareholders.

This is because, (1) EPS can lead to wrong decision making, if it is not related to the assessment and analysis of the income statement; (2) reported EPS cannot be compared over time between companies; and (3) EPS only focuses investors' attention on a single number without paying attention to the company as a whole which can provide information about the source and characteristics of earnings and provide a basis for profit and dividend projections (Widiharti, 2011:65). The results of this study indicate that the company prefers to withhold earnings rather than distribute it as cash dividends. Companies that are "growing" will pay cash dividends in small amounts or pay no dividends because their policy is to expand rapidly as far as internal and external financial conditions allow. This is related to the amount of retained earnings which is also the basis for calculating dividends. The company every year if it makes a profit is expected to pay cash dividends to its owners. If not all of them are declared to be distributed as dividends, it means that there is some retained earnings, which are usually used by the company for business development. In addition, the existence of net profit which is the basis for dividend distribution is often not balanced with the availability of cash to be used for cash dividend payments. So that large profits do not mean that the company can pay cash dividends in large amounts.

\section{Effect of Operating Cash Flow on Cash dividend}

The test results of this study indicate that the variable Effect of Operating Cash Flow on Cash dividends has no effect, which is indicated by the value of tcount $<$ ttable $(-1.106<-2.040)$ and the level of influence is $0.277>0.05$. These results do not support the previously proposed $\mathrm{H} 2$ or it can be said that the hypothesis is rejected. These results indicate that the operating cash flow generated by the company has no effect on the amount of dividends distributed to shareholders. This is because growing companies use large amounts of cash for the purpose of paying for inventories. Stice, et al (2009:282) in Agung (2013) stated that a positive cash flow indicates that the business can continue to run for now. However, when the cash flow owned by the company is inadequate and the company cannot obtain alternative financing in a short time, the company cannot freely use the cash, including paying dividends.

Thus, companies that produce positive operating cash flows may not necessarily be able to pay high dividends to their shareholders because the cash is used to optimize the company's capital. However, it also depends on the company's needs in managing the operating cash flow, when the company allocates more cash to increase 
capital, invest or pay obligations other than dividends. Or vice versa, companies that experience a decrease in cash income from operational activities, to maintain the impression on investors to prefer to pay cash dividends to investors. This is in line with the results of research conducted by Dafid Irawan and Nurdhiana (2012) which states that Operating Cash Flow has no effect on dividend policy.

\section{Effect of Free Cash Flow on Cash dividend}

The test results of this study indicate that the variable Effect of Free Cash Flow on Cash dividends has no effect as indicated by the value of tcount $<-$ ttable $(-0.027<$ -2.040 ) and the level of influence is $0.979>0.05$. These results do not support the H3 that has been proposed previously. or it can be said that the hypothesis is rejected. The results of this study are in accordance with research conducted by Hatta (2002) which states that Free Cash Flow has no effect on the dividend payout ratio. The greater the company's cash position, the greater the company's ability to pay dividends. The cash position factor that is actually available to shareholders will be reflected in the free cash flow owned by the company to be distributed to investors. If the condition of free cash flow applies continuously, then the present value of free cash flow will be even greater, and the value of the company will be greater in the eyes of investors. However, this amount is not always used to be distributed to shareholders as cash dividends. This is because the company anticipates increasing investment needs in the years to come. Various conditions of the company can affect the value of free cash flow, for example if the company has high free cash flow with low growth rate then this free cash flow should be distributed to shareholders, but if the company has high free cash flow and high growth rate then this free cash flow temporarily held and can be used for investment in the future period.

Due to the above conditions, it indicates that the presence of large free cash flows in a company does not necessarily indicate that the company will distribute dividends in larger amounts than when the company has small free cash flows. In accordance with the residual dividend policy theory, it states that the dividends paid are the remainder of the company's profits after deducting those paid to finance the company's capital planning (Weston and Brigham in Rosdini, No Year). This means that the company pays dividends only if there is an excess of funds over the company's profits that are used to finance the planned project. The basis of this policy is that investors prefer companies to hold and reinvest profits rather than distribute them in the form of dividends if the reinvested profits can generate higher returns than the average return that investors can generate from other investments with comparable risk. . If the company needs large enough funds to finance its investment or the company is growing so that most of its funds are embedded in fixed assets and working capital, its ability to pay cash dividends is also very limited. 


\section{Effect of Previous Year's Cash Dividend Payment on Current Year's Cash Dividend}

The test results of this study indicate that the previous year's cash dividend effect on cash dividend has an effect, which is indicated by the value of tcount $<$ ttable $(2.635<-2.040)$ and the level of influence is $0.013<0.05$. The results of this study are in accordance with research conducted by Danussiswanta (2002) which states that the distribution of cash dividends in the previous year has a significant effect on the distribution of dividends for the current year. The same result is also shown by research conducted by Ramli and Arfan (2011) which shows that the previous year's cash dividend has an effect on the cash dividend.

Ross (1977) in Danussiswanta (2002) in his research proves that an increase in dividend payments can create clear and unbeatable conditions on the market that the company's prospects have progressed. These results support Lintner's theory (Danussiswanta, 2002). which states that the independent variable of previous dividend distribution affects the current year's dividend distribution. In accordance with the dividend irrelevance theory proposed by Merton H. Miller and Franco Modigliani, the company will be attractive to shareholders whose preferences are related to dividend payments and stability are related to the payment pattern and the stability of the company's pattern itself. Investors want stable dividends as a source of income embedded in shares that are paid the same amount of dividends every period (Sundjaja and Barlian, 2003).

\section{CONCLUSION}

Based on the data obtained and the analysis that has been carried out, the conclusions that can be drawn from this study are as follows: Existing research, it can be concluded that net profit has no effect on cash dividends in food and beverage subsector manufacturing companies listed on the Stock Exchange. Indonesia for the period 2014-2018. Existing research, it can be concluded that Operating Cash Flow has no effect on cash dividends in food and beverage sub-sector manufacturing companies listed on the Indonesia Stock Exchange for the period 2014-2018. Existing research, it can be concluded that Free Cash Flow has no effect on cash dividends in food and beverage sub-sector manufacturing companies listed on the Indonesia Stock Exchange for the period 2014-2018. Existing research, it can be concluded that the previous year's cash dividends have an effect on the cash dividend, in the food and beverage sub-sector manufacturing companies listed on the Indonesia Stock Exchange for the period 2014-2018.

\section{Recommendations}

By paying attention to the results of the analysis and testing that have been concluded above, the authors try to provide suggestions such as the following: Companies should pay attention to cash dividend payments in previous years as an independent variable that affects the current year's cash dividends. Because the 
company will be attractive to shareholders whose preferences are related to dividend payout and stability. Investors want a stable dividend as a source of income embedded in shares that are paid the same amount of dividends every period. For investors and potential investors, it is better to pay attention to information in the form of policies owned by the company to help make decisions in their investment, especially regarding the payment of the previous year's cash dividend, which can affect the current year's cash dividend.

In addition, investors and potential investors should not only assume that dividend policy is only influenced by profit, Operating Cash Flow, Free Cash Flow, and previous year's cash dividend payments, but also have to look at other factors that can also affect the amount of cash dividends. that will be accepted, such as Return On Investment (ROI), Current Ratio, and Debt to Asset Ratio. For further researchers, it is better to add the number of samples within 6 years or 7 years of observation, adding other variables such as Analyzing the relationship between Net profit, Operating Cash Flow with cash dividends, or the effect of accounting profit, cash profit, Free Cash Flow, Operating Cash Flow, leverage and current ratio to Cash dividend. and can expand the research sample, not only to manufacturing companies but to more than one type of company such as mining companies, the consumer goods industry sector so that the results can be compared between one company with another.

\section{ACKNOWLEDGEMENT}

The Chancellor and the leadership at Terbuka University, Banten Indonesia

\section{REFERENCES}

[1] Brigham, Eugene F. dan Joel F. Houston. 2006. Fundamentals of Financial Management. 10th Edition. Dialihbahasakan oleh Ali Akbar Yulianto. DasarDasarManajemen Keuangan. Buku 2. Edisi 10. Jakarta: Salemba Empat.

[2] Brigham, Eugene F. dan Joel F. Houston 2009. Fundamentals of Financial Management. 10th Edition. Dialih bahasakan oleh Ali Akbar Yulianto. Dasar-Dasar Manajemen Keuangan. Buku 1. Edisi 10. Jakarta: Salemba Empat.

[3] Danusiswanta, Suparna Yusup. 2002. Pengaruh Arus Kas dan Dividen TahunSebelumnya Terhadap Pembagian Dividen pada Perusahaan Manufaktur di Bursa EfekJakarta Periode 1996-1998. Tesis Magister Sains Akuntansi. Semarang: Universitas Diponegoro.

[4] Darsono dan Ashari. 2005. Pedoman Praktis Memahami Laporan Keuangan. Yogyakarta: Penerbit Andi.

[5] Dyah Handayani Bs 2010, Analisis Faktor-Faktor Yang Mempengaruhi Dividen Payout Ratio Pada Perusahaan Manufaktur Di Bursa Efek Indonesia Periode 20052007

[6] Harahap, Sofyan Syafri. 2008. Teori Akuntansi. Jakarta: Rajawali Pers. Hariyanto Agus. 2013. Pengaruh Free Cash Flow, Profitabilitas, dan Likuiditas Terhadap Dividend Payout Ratio (Studi Empiris pada Perusahaan Manufaktur yang Terdaftar diBursa Efek Indonesia Periode 2007-2010). Bekasi: Universitas Islam“45”. 
[7] Hasan, Iqbal. 2001. Pokok-Pokok Materi Statistik 1 (Statistik Deskriptif). Edisi Kedua. Jakarta: PT Bumi Aksara.2002.Pokok-Pokok Materi Statistik 2 (Statistik Inferensif). Edisi Kedua. Jakarta: PT Bumi Aksara. Hatta, Atika Jauhari. 2002. Faktor-Faktor yang Mempengaruhi Kebijakan Dividen :Investigasi Pengaruh Teori Stakeholder pada Perusahaan Manufaktur yang Terdaftar di Bursa Efek Jakarta Periode 1993-1999. JAAI Vol. 6, No. 2.

[8] Hermi. 2004. Hubungan Net profit dan Operating Cash Flow Terhadap Cash dividend pada Perusahaan Perdagangan Besar Barang Produksi di Bursa Efek JakartaPeriode 1999-2002. Media Riset Akuntansi, Auditing, dan Informasi Vol. 4, No. 3 Desember 2004, Pp.247-258.

[9] Hijriani, Agitsni. 2012. Pengaruh Economic Value Added (EVA) dan Return On Equity (ROE) Terhadap Perubahan Harga Saham pada Perusahaan Manufaktur yangTerdaftar di Bursa Efek Indonesia. Bekasi: Universitas Islam “45”.

[10] Ika Sri Viviani 2018 Pengaruh Kesempatan Investasi, Net profit, Free Cash Flow, Dan Pertumbuhan Perusahaan Terhadap Kebijakan Dividen Reza Winnar Nugroho 2018 Pengaruh Operating Cash Flow Dan Laba Akuntansi Terhadap Retrun Saham

[11] Lusi Septriana, Prima Aprilyani Rambe, Hj. Asmaul Husna 2012-2014 , Pengaruh Laba Akuntansi, Laba Tunai, Free Cash Flow, Operating Cash Flow, Leverage Dan Current Ratio Terhadap Cash dividend Pada Perusahaan Manufaktur Yang Terdaftar Di Bei Tahun 2012-2014

[12] Murni Mayang Putri 2019 Pengaruh Operating Cash Flow Dan Net profit Terhadap Deviden Tunai Pada Perusahaan Makanan Dan Minuman Yang Terdaftar Di Bursa Efek Indonesia 2013-2017

[13] Nur Cahyati 2017 Pengaruh Arus Kas Aktivitas Operasi, Investasi, Dan Pendanaan Terhadap Likuiditas Perusahaan Sub Sektor Tekstil Dan Garmen Yang Terdaftar Di Bursa Efek Indonesia Periode 2011-2015

[14] Sofiani Us Watun Hasanah 2019 Pengaruh Arus Kas Dan Likuiditas Terhadap Profitabilitas Perusahaan Manufaktur Sub Sektor Makanan Dan Minuman Yang Terdaftar Di Bursa Efek Indonesia Periode 2009-2018 